San Jose State University

SJSU ScholarWorks

Master's Theses

Master's Theses and Graduate Research

1997

\title{
Effects of disturbance on sea otters (Enhydra lutris) near Monterey, California
}

James Michael Curland

San Jose State University

Follow this and additional works at: https://scholarworks.sjsu.edu/etd_theses

\section{Recommended Citation}

Curland, James Michael, "Effects of disturbance on sea otters (Enhydra lutris) near Monterey, California" (1997). Master's Theses. 1431.

DOI: https://doi.org/10.31979/etd.3uq8-da46

https://scholarworks.sjsu.edu/etd_theses/1431

This Thesis is brought to you for free and open access by the Master's Theses and Graduate Research at SJSU ScholarWorks. It has been accepted for inclusion in Master's Theses by an authorized administrator of SJSU ScholarWorks. For more information, please contact scholarworks@sjsu.edu. 


\section{INFORMATION TO USERS}

This manuscript has been reproduced from the microfilm master. UMI films the text directly from the original or copy submitted. Thus, some thesis and dissertation copies are in typewriter face, while others may be from any type of computer printer.

The quality of this reproduction is dependent upon the quality of the copy submitted. Broken or indistinct print, colored or poor quality illustrations and photographs, print bleedthrough, substandard margins, and improper alignment can adversely affect reproduction.

In the unlikely event that the author did not send UMI a complete manuscript and there are missing pages, these will be noted. Also, if unauthorized copyright material had to be removed, a note will indicate the deletion.

Oversize materials (e.g., maps, drawings, charts) are reproduced by sectioning the original, beginning at the upper left-hand comer and continuing from left to right in equal sections with small overlaps. Each original is also photographed in one exposure and is included in reduced form at the back of the book.

Photographs included in the original manuscript have been reproduced xerographically in this copy. Higher quality 6" $\times$ 9" black and white photographic prints are available for any photographs or illustrations appearing in this copy for an additional charge. Contact UMI directly to order.

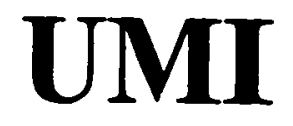

A Bell \& Howell Information Company 



\title{
EFFECTS OF DISTURBANCE ON SEA OTTERS (Enhydra lutris) NEAR MONTEREY, CALIFORNIA
}

A Thesis Presented to the Faculty

of

San Jose State University

through

Moss Landing Marine Laboratories

\author{
In Partial Fulfillment \\ of the Requirements for the Degree \\ Master of Science in Marine Science
}

by

James Michael Curland

May 1997 
UMI Number: 1384680

Copyright 1997 by

Curland, James Michael

All rights reserved.

UMI Microform 1384680

Copyright 1997, by UMI Company. All rights reserved.

This microform edition is protected against unauthorized copying under Title 17, United States Code.

\section{UMI \\ 300 North Zeeb Road \\ Ann Arbor, MI 48103}


APPROVED FOR THE DEPARTMENT OF MARINE SCIENCES Tamot Dr. James Harvey

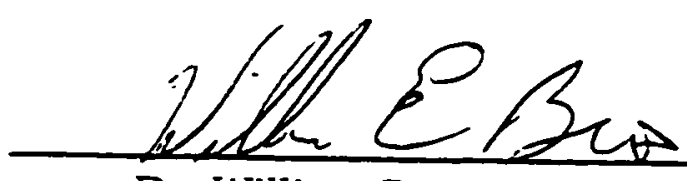

Dr. William Bros

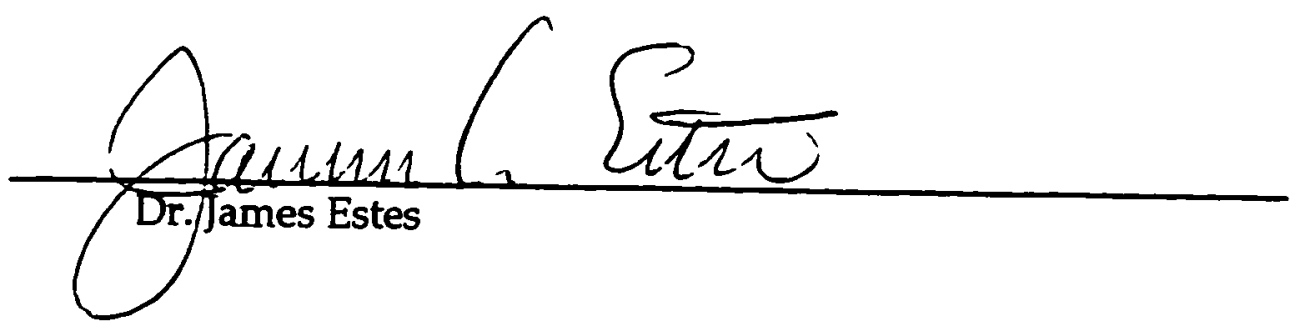

APPROVED FOR THE UNIVERSITY

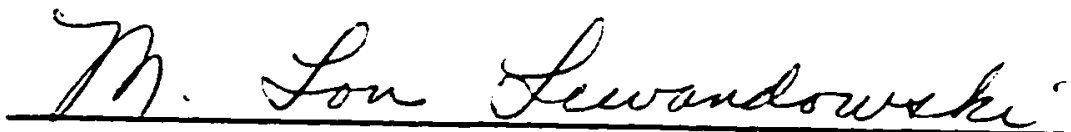


(C) 1997

James Michael Curland

ALL RIGHTS RESERVED 


\section{ABSTRACT \\ EFFECTS OF DISTURBANCE ON SEA OTTERS (Enhydra lutris) NEAR MONTEREY, CALIFORNIA

\author{
by James M. Curland
}

The southern sea otter, which spends $80 \%$ of their time at the water's surface, might be more affected by kayaking and boating than other marine mammals that spend most of their time underwater. I investigated the types and levels of human activities and their effects on sea otter behavior in Monterey Bay, California. Percentage of time sea otters spent resting, grooming, foraging, traveling, and interacting were recorded using focal sampling, and compared between areas with and without disturbance. The amount of activity from kayaks, boats, and divers was measured at each area. Kayaks were the major source of potential disturbance in the near-shore waters off Cannery Row. In areas with disturbance sea otters were engaged in significantly greater levels of travel (13\%) than in areas without disturbance (5\%). It appears that human activities may cause sea otters to spend more time traveling within and out of areas with disturbance. 


\section{ACKNOWLEDGMENTS}

My heartfelt appreciation goes to the many people who helped this dream become a reality. There were many of life's obstacles that surfaced during this project. I really thank everyone for their faith in me and providing those words of encouragement when things looked dismal.

I would like to expressly thank Dr. Jim Harvey, graduate thesis advisor, and my other two committee members, Dr. William Bros and Dr. James Estes, for all their support and encouragement. Dr. Harvey's patience, understanding, and guidance kept me on track and from losing sight of my objectives at Moss Landing Marine Laboratories. The focus and inspiration that Dr. Bros offered in a time of crisis was immeasurable. The willingness of Dr. Estes to join my committee and provide the input and assistance at a moments' notice is greatly appreciated.

I would not be where I am today without the support, encouragement, sacrifices, and love from Pamela Byrnes. When I really felt like quitting, Pamela was there to bolster my confidence and inspire me to forge onward.

This project would not have been completed without the incredible assistance, friendship, and support from the following people: Jim and Linda Kanihan, Ky Springer, Kim and Rob Suryan, Lisa Uttal, Jonah Roll, Helene Harris, Suzanne Rosenthal, George Rosenthal, Marianne Riedman, Michelle Staedler, Jerry Loomis, Scott Kathey, Brian Hatfield, Ron Jameson, Sheila and 
Alan Baldridge, Gail Johnston, Mary Yoklavich, Lynn McMasters, Tony Orr, Tomo Eguchi, Dion Oxman, Ted and Peg Byrnes, Dr. Fuad Freiha, Dr. Michael Alexander, Dr. Frank Brau, Larry Morkert, Julie Martin-Pitts, Joe and Nancy Caesar and everyone from the Dominican Hospital Cancer Support Group, and, finally, all others.

The field work would not have been possible if it weren't for the invaluable assistance from the countless flow of the famous "Jim Harvey Interns" (which ranged from far and near), especially Oliver Boiusseau, Hayley Gay, and Kim Hayes. Also an immense gratitude goes to the invaluable help from the Earthwatch crew of 1992, directed by Pamela Byrnes.

The following people from San Jose State University were extremely patient and offered great assistance: David Sharp, Janet Elliott, and Coleeta McElroy.

I would like to thank the following people/organizations for financial assistance: Earl \& Ethyl Myers Marine Biology Trust Fund, The Kaempfer Company, Ms. Kathleen Kennedy \& Mr. Frank Marshall, Mr. Murray Pepper, Mr. Mads Bjerre, Mr. Ron Popeil, Mr. Sherwood Weiser, Ms. Jeanette Thomas, Ms. Thea Pairman, and Mr. Chris Smart.

Lastly, I want to thank my parents, Robert \& Lillian Curland; brother, Rob Curland; and my grandmother, Dorothy Curland for their continual love, support, and faith that I wouldn't give up and this dream would be realized. 


\section{TABLE OF CONTENTS}

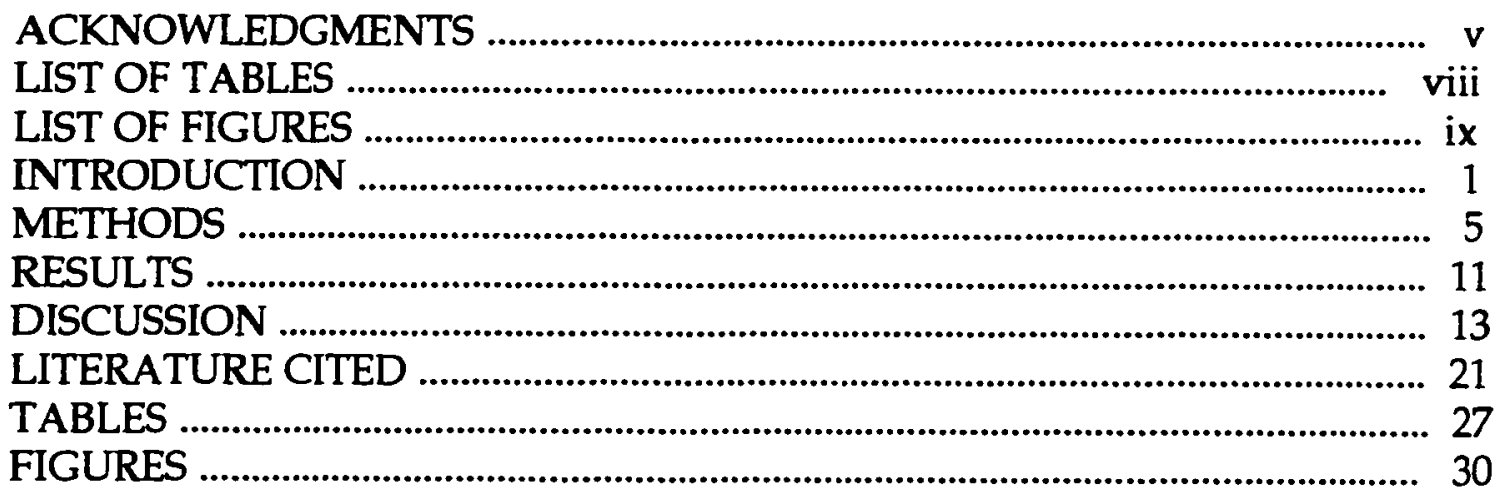




\section{LIST OF TABLES}

Page

Table 1. Classification of sea otter discrete action patterns used 27 in this study into functional behavioral states.

Table 2. Types and levels of disturbance (kayaks, boats, and divers) for the four areas with disturbance in Monterey Bay, California.

Table 3. Associations between percentage of time sea otters engaged in resting, grooming, foraging, traveling, and interacting as a function of type of study area, period of day, and season. This was tested using hierarchical loglinear analyses. 


\section{LIST OF FIGURES}

Figure 1 a,b. Monterey Bay, California study area.

Figure $1 \mathrm{c-g}$. Locations and boundaries (indicated by hatching) of study areas with and without disturbance in Monterey Bay, California.

Figure 2. The mean percentage of time sea otters engaged in resting, grooming, foraging, traveling, and interacting in areas with and without disturbance in Monterey Bay, California.

Figure 3. The percentage of time sea otters spent in high and low levels of grooming in areas with and without disturbance in Monterey Bay, California. The total percent time for each level of grooming in areas with and without disturbance was compared between seasons (mid spring to mid summer, late summer to fall).

Figure 4. The percentage of time sea otters spent in high level ( $>$ mean) and low level ( $\leq$ mean) travel for areas with and without disturbance in Monterey Bay, California. 


\section{Introduction}

There have been various studies on the effects of ambient and manmade noise on marine animals (Dufour 1980; Riedman 1983; Riedman 1984a, 1984b; Richardson et al. 1985a, 1985b, 1986, 1991; Gladwin and Manci 1988;

Manci et al. 1988; Majors and Myrick, Jr. 1990; Myrberg, Jr. 1990; Cosens and Dueck 1993). Seven major categories of behavioral responses (fright, startle or orienting response; abnormal behavior patterns; weakened reflexes; learning decrements; avoidance; no response, habituation, or adaptation; and attraction to the noise or noisy area) to noise disturbance were listed by Dufour (1980), although other disturbances may illicit all or some of these behavioral responses. Effects of industrial noise (sounds associated with petroleum industry activities) on sea otters has been investigated near Soberanes Point, California (Riedman 1984a, 1984b). Behavior, density, and distribution of sea otters in this area were unaffected during acoustic experiments. Riedman stated: "sea otters were seemingly undisturbed by experimentally projected waterborne industrial and seismic noise or by recordings of killer whale (Orcinus orca) vocalizations."

The physical presence of human activities (eliminating the acoustical variable) and its effects on marine animals have been documented in numerous cases (Anderson and Keith 1980; Burger 1981; Baker et al. 1983; Mansfield 1983; VanDerZande and Verstrael 1985; Watkins 1986; Anderson 
1988; Piatt et al. 1990; Burger and Gochfeld 1993; Smith 1993; Beja 1996).

Human recreational activities have disrupted nesting and roosting in marine birds and reduced their breeding success (Anderson and Keith 1980; Burger 1981; VanDerZande and Verstrael 1985; Anderson 1988; Piatt et al. 1990;

Burger and Gochfeld 1993; Mikola et al. 1994). Recreationists, scientists, fishermen, and educational groups had disrupted breeding of the California Brown pelican (Pelecanusoccidentalis californicus) and Heerman gull (Larus heermanni) in the Gulf of California and off the west coast of Baja California (Anderson and Keith 1980). Kestrel (Falco tinnunculus) breeding success and distribution may be influenced by outdoor recreation and proximity of human disturbance (VanDerZande and Verstrael 1985). Burger and Gochfeld (1993) found the response of Masked (Sula dactylagra), Red-footed (Sula sula), and Blue-footed (Sula nebouxii) boobies (flying, walking, or remaining on their display stations) was related to their distances from tourist trails. For all three species of boobies observed, if they were over 6 meters from a tourist trail they showed very little response to human activity. If boobies were within 2 meters of the trails they responded by walking or flying away from their display stations more than $62 \%$ of the time.

In some locations, vessel traffic has affected the spatial distribution, movement pattern, and reduced the abundance of birds and marine mammals (Sorensen et al. 1984; Thiel et al. 1992; Mikola et al. 1994). Thiel et al. (1992) found that boating accounted for $75 \%$ of the disturbances 
influencing the spatial distribution of the harbor seal (Phoca vitulina), moulting Eider (Somateria mollissima), and Shelduck (Tadorna tadorna). Vessel traffic also affects cetacean behavior by altering their swimming speed, dive times, respiratory patterns, and degrees of vigilance (Baker et al. 1983; Richardson et al. 1985a, 1985b; Watkins 1986; Kruse 1991; Corkeron 1995; Suryan 1995). In the Eastern Beaufort Sea, the bowhead whale (Balaena mysticetus) reacted more strongly to close approach by various boats than to any other industrial activity (Richardson et al. 1985a, 1985b). Bowheads swam away rapidly when boats approached within 1 to $4 \mathrm{~km}$. Humpback whales (Megaptera novaeangliae) off Alaska significantly changed their respiratory patterns relative to vessel speed, vessel proximity, and presence of large ships (Baker et al. 1983). Harbor seals (Phoca vitulina richardsi) in Washington increased their vigilance in response to boating activity (Suryan 1995). The distances at which harbor seals were disturbed and the level of disturbance (detection, alarm, and harassment) varied by region, type of vessel (powerboats, kayaks), and vessel speed. In Johnstone Strait, British Columbia, Kruse (1991) reported that the killer whale (Orcinus orca) responded to approaching boats by increasing their swimming velocities and swimming toward open water. Short-term and long-term stress in killer whales was considered to result from boating disturbances (the presence of boating activity without factoring in noise effects). 
Kayaking, jet skiing, boating, and other recreational activities might have a greater effect on marine animals that spend much of their time on the water's surface compared to those species that primarily are below the surface. The southern sea otter, which spends approximately $80 \%$ of its' time on the water's surface (Riedman pers. comm.) might be more affected by these recreational activities. Kayaking is the activity most frequently encountered by sea otters off Monterey.

Quantifying the affects of kayaking, jet skiing, boating and other recreational activities on sea otter behavior would appear important given the precarious state of the southern sea otter population. The present range of the southern sea otter is from Año Nuevo Point to Purisima Point, California. Riedman et al. (1994) observed a high preweaning pup mortality associated with the California population, which accounts for their relatively slow growth rate $(5-6 \%$ per year increase compared to the nearly $20 \%$ increase per year seen in the northern population). During 1996, a population census of southern sea otters indicated there were 2,278 individuals (including 315 pups) in the spring and 2,019 individuals (including 161 pups) in the fall (Hatfield pers. comm.). Spring, 1992 was the first time the California population had numbered greater than 2,000 individuals since commercial exploitation began.

The southern sea otter is listed as a "threatened population" under the Endangered Species Act, and is protected under the Marine Mammal 
Protection Act. The establishment of the Monterey Bay National Marine Sanctuary could further protect southern sea otters. Further rules and regulations, as well as clarification of existing ones, with regard to approaching marine mammals is reported in a document compiled by NOAA (K. Miller 1992). Human recreational activities, which may pose a threat to sea otters, have not been monitored by state and federal agencies and their affects on sea otter behavior are unknown.

The objectives of this research were to 1) document the types of human disturbances and 2) record their effects on sea otter behavior. Based on these objectives the following hypotheses were postulated apriori: 1) sea otters spend a greater percentage of their time grooming, feeding, and resting in areas without disturbance compared to areas with disturbance, and 2) sea otters, in areas with disturbance, spend more time traveling than in areas without disturbance.

\section{Methods}

The daily activity budgets of sea otters (Shimek and Monk 1977; Estes et al. 1986; Ralls \& Siniff 1990) were described using 26 discrete action patterns grouped into five broad behavioral states (Resting, Grooming, Foraging, Traveling, and Interacting; Table 1). Packard and Ribic (1982) found that, "while the general activity categories of feeding and resting were distinctive 
enough to allow reliable identification by observers, the categories of grooming, locomotion, and interaction showed considerably more overlap."

To estimate percentage of time sea otters were in five behavioral states (Table I) I used focal sampling (Altmann 1974) from land-based stations, which Estes and Jameson (1988) reported had a high sighting probability. These five categories of behavior were then used to monitor human disturbance by contrasting the percentage of time sea otters engaged in these activities between areas with and without disturbance. Various types of potential disturbances were recorded, which included kayaks, jet-skiers, boats/zodiacs, and divers. Disturbance in this study, was defined as any human recreational activity which had the potential, due to its presence and proximity to sea otters, to alter the behavior of sea otters before the introduction of the human activity.

One sea otter, chosen at random in a study area, was observed using a spotting scope or binoculars for 30-minute duration. Thirty minute observational periods were selected because I believe it recorded an accurate ethogram, or behavior profile, of sea otters and it enabled me to conduct more observations per day than if I had a longer time period. This selected duration also afforded the chance for human activities, which were discontinuous and unpredictable, to occur. Observations shorter than a 30minute duration would not have documented a reliable ethogram or accurate picture of the levels of human activities. If there was more than one sea otter 
in the study area, a second animal, chosen randomly, was observed after a 15minute break from the first observation. This break between observations was to provide independence for each of the observations. I wanted to minimize the potential that a second animals' behavior was affected by the focal animal in the first observational period. The survey was terminated and the data were not used in the final analysis if the focal otter exited the study area before the 30 minute observation had concluded. This was done to standardize all the observations for the same duration. In 1992, when many volunteers assisted with sampling, there were several occasions when more than one otter was observed during the same 30 -minute period. To avoid the problems associated with pseudoreplication (Hurlbert 1984), if more than one sea otter was observed during a 30-minute period, the data were pooled and means were calculated for the percentage of time sea otters were engaged in each of the five behavior states.

Data were collected at a total of seven study areas with and without disturbance in Monterey Bay, California (Fig. 1). To determine if there was a significant difference in the levels of human activities between areas with and without disturbance, I compared the mean number of disturbances for the total number of kayaks, boats, and divers for the two areas. Because the sample size differed among the seven study areas, I used an average of nine (the smallest sample size for any of the study areas) observations chosen randomly from each area to calculate the means. Due to unequal variances 
among the study areas, a Mann-Whitney Test was used. There was significantly greater amounts of human activities $(\bar{x}=5.8)$ in areas with disturbance than areas without disturbance $(\bar{x}=0 ; U=12, p=0.026)$.

Areas that were considered to have disturbance (mean number of disturbance activities/observation was greater than 2; Fig.1) included: 1) nearshore waters around Cannery Row (HD-1), 2) near-shore waters adjacent to Monterey coast guard wharf (HD-2), 3) Point Lobos Reserve-Whalers Cove (HD-3), and 4) Lovers Point (HD-4). Areas without disturbance (0 disturbance activities/observation; Fig.1) included: 1) Point Lobos Reserve-Headland Cove (ND-1), 2) Soberanes Point-Garrapata State Park (ND-2), and 3) Unidentified Cove (below Hwy 1 vista point 0.4 miles south of Garrapata Creek, between Kasler Point and Notley's Landing; ND-3). Boundaries of each site were determined by kelp canopy and physical landmarks. These seven study areas were sampled between 0900 and 1700h, January through November, 1992 and May through November, 1993 (except for inclement weather). Usually at least one area with disturbance and one without disturbance was sampled per day.

Period of day (morning: 0900 to 1230, and afternoon: 1231 to 1700) was recorded during each sample. Southern sea otters' diurnal activity cycles are characterized by crepuscular peaks in foraging activity and a midday (late morning to late afternoon) period of rest. Researchers have observed that the percentage of time allocated to five behavioral states during daylight hours have the following ranges: resting, 51-63\%; foraging , 21-28\%; grooming, 5- 
16\%; interacting, 0-8\%; and traveling, 2-9\% (Shimek and Monk 1977; Estes et al. 1986). Period of day was recorded to test whether activity patterns differed between areas with and without disturbance and does the period of day have an affect?

Season (mid spring to mid summer, May-July, and late summer to fall, August-November) was also recorded during each sample. In California the seasons are less pronounced and my sampling period only covered mid spring through fall. It seems that there would be a difference in the levels of human recreational activities dependent on season (more activity during the spring and summer and less in fall and winter). I included season as a factor to test whether season affected sea otter behavior in areas with disturbance compared to areas without disturbance.

Analysis: Samples from both years (1992 and 1993) were pooled because any significant differences between those two years could not accurately be tested given the limitation of only two years of data. To accurately test differences among years, more than two years of data were required. The percentage of time animals were engaged in each of the five behavioral states was calculated for each 30-minute focal sample, and study area; period of day; season; and other notes on the survey were entered into a statistical software program (Systat).

In this study, the activity budget of sea otters (percentage of time engaged in each of the five behavioral states) was studied as a function of 
three factors: 1) type of study area (areas with disturbance and areas without disturbance), 2) period of day (morning and afternoon), and 3) season (mid spring to mid summer and late summer to fall). All associations among sea otter behaviors (resting, grooming, foraging, traveling, and interacting) and these factors were tested using a hierarchical loglinear analysis (Norusis 1994; Tabachnick and Fidell 1996). In this type of analysis, questions about associations are translated into "tests of main effects" (in this case, associations between sea otter behavior and each of the three factors) and "interactions" (in this case, association between sea otter behavior and the joint effects of two and three factors). Due to a small sample size in conjunction with all combinations of variables not being possible, which can drastically reduce the power for testing these associations, a Bonferroni correction was used to maintain overall probability of 0.05 for Type I error (Norusis 1994; Tabachnick and Fidell 1996).

For analysis data were coded into two categories. For each focal animal observation, the percentage of time the sea otter engaged in resting, grooming, foraging, traveling, and interacting was coded as either high level ( $>$ mean for all observations in each behavior category) or low level $\leq$ mean for all observations in each behavior category); study areas were coded as either areas with disturbance or areas without disturbance; period of day was coded as either morning or afternoon; and season was coded as either mid spring to mid summer or late summer to fall. Frequencies of all the 
associations were then calculated and used to run the hierarchical loglinear analyses and all three-way associations, two-way associations, and all individual factors were tested for significance.

\section{Results}

Kayaks were the predominant source of human disturbance for study areas HD-1 (76.5\% of total disturbances in the area) and HD-2 (78.0\% of total disturbances; Table 2). Boats (zodiacs, fishing boats, tour boats, and sailboats) accounted for most of the other sources of human disturbance in HD-1 (15.5\% of total disturbances) and HD-2 (13.1\% of total disturbances; Table 2). Divers were the predominant source of human disturbance for HD-3 (84.3\% of total disturbances) and HD-4 (56.7\% of total disturbances; Table 2). Other sources of human activity in areas with disturbance included planes, sonic booms, people on trails close to shore, and military testing at Fort Ord. Jet skiers were observed on only two occasions.

In areas without disturbance, sea otters mostly rested (mean $=64 \%, \mathrm{SE}$ $=0.04$ ) and least often traveled (mean $=5 \%, \mathrm{SE}=0.02, n=66 ;$ Fig. 2 ). In areas with disturbance, sea otters spent an average of $58 \%$ of the time resting (SE = 0.03 ) and the least amount of time interacting (mean $=5 \%, \mathrm{SE}=0.01, n=112$; Fig. 2). Sea otters engaged in traveling $13 \%$ of the time in areas with disturbance areas, whereas only $5 \%$ of the time were they traveling in areas 
without disturbance.

There was no significant dependence between the frequency of time sea otters spent resting and any two or three-way associations with type of study area, period of day, or season (Table 3).

There was a significant three-way association for the time sea otters engaged in high and low levels of grooming with the type of study area and season ( $p=0.015$; Table 3 ), but there was no association between period of day. In areas with disturbance, $62 \%$ of the time sea otters engaged in high levels of grooming in mid spring to mid summer versus $38 \%$ in late summer through fall (Fig. 3). In areas without disturbance, $70 \%$ of the time sea otters engaged in high levels of grooming in late summer through fall versus $30 \%$ in mid spring to mid summer. In areas with disturbance, $59 \%$ of the time sea otters engaged in low levels of grooming in late summer through fall versus $41 \%$ in mid spring to mid summer.

There was no significant dependence between the frequency of time sea otters spent foraging or interacting and any two or three-way associations with type of study area, period of day, and season (Table 3).

In areas with disturbance, sea otters were engaged in high levels of traveling $32 \%$ of the time compared to areas without disturbance $(12 \% ; \mathrm{p}<$ 0.002; Table 3; Fig.3), but there was not an effect of season or period.

For the hypothesis that sea otters spent a greater percentage of time grooming, foraging, and resting in areas without disturbance versus areas 
with disturbance, only grooming was significant and this was dependent on season. For the hypothesis that sea otters, in areas with disturbance, spend more time traveling than in areas without disturbance, traveling was significantly different and it was dependent only on the type of study area.

\section{Discussion}

One of the goals of this study was to identify the sources of human disturbance that might potentially affect sea otter behavior in Monterey Bay. Kayaks were the recreational vessel most often seen in the near-shore waters off Cannery Row in Monterey Bay, whereas divers were most often seen at Whalers Cove and Lovers Point. The latter two study areas mentioned are not as accessible to kayaks, but the near-shore waters off Cannery Row are extremely accessible to kayaks. Divers were more often seen at Whalers Cove, which is probably due to its easy and protected access to a part of the Monterey coast which is within a state reserve.

All surface human recreational activities, such as kayaking, boating, jet-skiing, etc. are easier to monitor than diving with respect to their potential affect on sea otter behavior. Kayaks appear more unobtrusive and generate less noise than motor boats and jet skis, which might allow them to approach sea otters more closely before the sea otter is aware of their presence. Sea otters' sense of hearing is not well known; so it is difficult to assess the point 
at which sea otters hear noise related to disturbance activities. It seems that, even if there were information on their sense of hearing, it would be difficult to quantify whether sea otters first responded to a visual or acoustical stimuli. Because I could not account for how the visual or auditory sense in sea otters was involved with their response to human disturbance, I determined that recording the presence of human recreational activities and how this potentially affected sea otter behavior and measuring the percent time they engaged in different behaviors would be an indirect way of assessing how disturbance affects them.

Only the percentage of time sea otters were observed resting, grooming, and interacting was within the range reported by previous researchers (Shimek and Monk 1977; Estes et al. 1986) for sea otter activity during daylight hours. The percentage of time sea otters engaged in foraging was below the range reported by researchers; while that for traveling was slightly above the range reported. But, there were not any dramatic differences for the amount of time sea otters spent resting, foraging, grooming, and interacting between areas with and without disturbance. However, the percentage of time sea otters spent traveling in areas with disturbance was significantly greater than in areas without disturbance. The lack of any significant differences in the percentage of time sea otters spent resting, foraging, grooming and interacting might have a lot to do with sea otters becoming more acclimated to the steady flow of activity in certain parts of Monterey Bay. 
Older and more experienced animals might become more acclimated to human activities by being more aware of their immediate surroundings and learning what types of activities are potential threats to their safety. The visual sense would be important in alerting an animal to these potential dangers. Visual acuity in sea otters is well developed above water and underwater (Riedman and Estes 1990). An enlarged ciliary apparatus enables them to focus clearly on targets both in air and water by relying on accommodation to compensate for losses due to refraction (T.D. Williams, pers. comm.). Looking, defined by Packard and Ribic (1982) as a discrete action pattern in sea otters, might resemble a form of vigilance. This discrete action pattern was not closely measured with respect to human disturbance in my study, but would be interesting to examine in future studies. There probably is no necessity for vigilance to be as developed in any animal who does not come into contact with much human activity. It has been suggested by Loomis and Estes (pers. comm.) that sea otters in remote areas, where human activity is at a minimum, are more wild and cautious of human activities since they are not frequently exposed to them.

Suryan (1995) found that the presence or absence of a potential disturbance, whether the disturbance was before or after an initial harassment, and the distance and speed of a vessel from a haul out site affected harbor seal vigilance in the San Juan Islands, Washington. Harbor seals at sites more often disturbed exhibited increased vigilance. 
Sea otter mothers with pups appeared more cautious of disturbances such as kayaks, boats, and divers, although there were no data collected for this relationship. Corkeron (1995) found that humpback whales with calves in Australia were less likely to exhibit a variety of surface behaviors and dove more often when boats were within $300 \mathrm{~m}$ compared to when boats were absent. The overall rate and in what sequence these surface behaviors occurred were the components that significantly changed. It would be interesting to look at the correlation between the frequency of sea otter dives and the presence and absence of disturbances.

Grooming was the only behavior of sea otters that had a significant association with type of study area (areas with disturbance vs. areas without disturbance) and season (mid spring to mid summer vs. late summer to fall). The association between time spent grooming and type of study area was not significant, but, including the factor of season created a significant association. I believe, given the seasons I conducted my study in Monterey Bay not being distinct weather-wise, any significance seen is more an artifact of experimental design and there does not appear to be any biological significance. Had I been able to gather any of my data in the winter, I could have examined the differences between the amount of human activity in winter compared to the spring and summer months, when recreational activity is at a high. 
Because 30-minute focal observations were terminated if the sea otter vacated the study area, traveling was probably underestimated in both areas with and without disturbance because animals exiting the area were traveling. With this factor and the unequal sampling it is difficult to determine if differences in the amount of traveling in areas with and without disturbance are an accurate reflection of the population. I believe, with a better sampling design and the addition of the discarded data (any observations that were less than the standardized 30 minute duration), the trend of more traveling in areas with disturbance would still be present. Because the level of traveling was significantly greater in areas with disturbance areas compared to areas without disturbance, independent of period of day and season, a greater difference may have been observed had these data been included. It needs to be examined more closely, but it appears that sea otters more frequently travel out of an area when human activity is present and also might be entirely absent from those areas.

Garshelis and Garshelis (1984) reported that when there was heavy boat traffic in Orca Inlet, Alaska from May-September, due to commercial fisheries, the numbers of male otters were less than those seen in this same area during winter months when boat traffic was light. They believed that "seasonal changes in disturbances from boats were largely responsible for seasonal movements among the male areas, and that boat traffic also deterred otters from using the regions between the various male areas." Sorenson et al. 
(1984) reported that the sighting probability of squid-eating cetaceans decreased with the presence of certain vessels. The relationship between the sighting probabilities of sea otters and the presence of human activities was not examined. This would be an interesting relationship to further research because it appears there may have been a correlation between the amount of human activity and whether sea otters were present at all.

From this study, I was able to determine which relationships between sea otter behavior and human activity would warrant further investigation. Certain factors such as mortality, chance environmental events, inherent variability among the measured factors, observer error, or unknown events during a study may alter the data, which causes factors to be confounded (Fowler 1990). A sound experimental design is used to help contrast factors. Numerous replicates are essential in order to accurately test any hypotheses that might involve small differences between means (Bros and Cowell 1987). Hurlbert (1984) stated that "replication, randomization, and independence have two functions in an experiment: they improve estimation and they permit testing." My study had randomization and independence but was lacking in the number of replicates for areas with and without disturbance. A more robust analysis would have been possible with a design of $>10$ areas with disturbance areas and $>10$ areas without disturbance with fewer observations at each study area. This would have allowed a better comparison of means for the percentage of time sea otters engaged in the five 
behavioral states. It would also allow more certainty that I sampled a good representation of the population.

I do not believe the clustering of my study areas with disturbance in one section of Monterey Bay and the clustering of my study areas without disturbance along the outer coastal areas near Monterey and Carmel affected my results for two reasons: 1) I assumed that within such a small range where I conducted my study, of the overall range for the southern sea otter, that sea otter behavior profiles did not differ significantly among my study areas, and 2) the rugged topography and rough ocean conditions for areas without disturbance are devoid of human activities due to those very features of the areas. They are less accessible than the areas with disturbance where human activities are more inviting.

The emphasis on sound experimental design and carefully stated questions observing the relationship of human activity and its' affect on wildlife behavior has prompted researchers in Canada to examine the recreational non-consumptive uses of wildlife, including killer whales (Duffus and Dearden 1990, 1993; Duffus and Wipond 1992). Nonconsumptive uses, with an emphasis on wildlife photography and viewing, are putting both an extra strain on declining wildlife populations and habitat losses. These strains are putting added demands on wildlife managers. The establishment of marine sanctuaries are a way to minimize the strain put on marine resources by consumptive and non-consumptive human use. 
Because recreational activities are a growing concern in Monterey Bay, a designated national marine sanctuary, answers to questions addressing whether distribution, movements, mating, reproductive success, foraging efficiency, and overall health are affected by disturbance may ensure that sea otters have an optimum habitat for continued population growth.

Future researchers may have the potential to quantify effects of disturbance on sea otter activity patterns based on distances from disturbance sources. Quantifying distances from the various sources of disturbance are useful to determine threshold distances. These distances may be used to implement regulations for approaching sea otters. Sea otters are one of the only marine mammals which have no clear state and federal regulations with regard to their "take." Their status as an endangered species indicates the need for protection. The Monterey Bay National Sanctuary is one way, and hopefully some of the results of this study and future studies will provide better understanding on how human recreational activities in Monterey Bay affect sea otter behavior. 


\section{Literature Cited}

Altmann, J. 1974. Observational study of behavior: sampling methods. Behavior. Vol. 4:227-267.

Anderson, D. W. 1988. Dose-response relationship between human disturbance and brown pelican breeding success. Wildl. Soc. Bull. 16:339-345.

Anderson, D. W. and J. O. Keith. 1980. The human influence on seabird nesting success: conservation implications. Biol. Conserv. 18:65-80.

Baker, C. S., Herman, L. M., Bays, B. G., and G. B. Bauer. 1983. The impact of vessel traffic on the behavior of humpback whales in southeast Alaska: 1982 season. Rep. from Kewalo Basin Mar. Mamm. Lab., Honolulu, HI, for U.S. National Mar. Mamm. Lab., Seattle, WA. 30 p. plus Figures and Tables.

Beja, P. R. 1996. Temporal and spatial patterns of rest-site use by four female otters Lutra lutra along the south-west coast of Portugal. J. Zool., Lond. 239:741-753.

Bros, W. E. and B. C. Cowell. 1987. A technique for optimizing sample size (replication). J. Exp. Mar. Biol. 114: 63-71.

Burger, J. 1981. The effect of human activity on birds at a coastal bay. Biol. Conserv. 21:231-241.

Burger, J. and M. Gochfeld. 1993. Tourism and short-term behavioural responses of nesting masked, red-footed, and blue-footed, boobies in the Galapagos. Env. Cons. 20(3):255-259. 
Corkeron, P. J. 1995. Humpback Whales (Megaptera novaeangliae) in Hervey Bay, Queensland: behaviour and responses to whale-watching vessels. Can. J. Zool. 73:1290-1299.

Cosens, S. E. and L. P. Dueck. 1993. Icebreaker noise in Lancaster Sound, N.W.T., Canada: implications for marine mammal behavior. Mar. Mamm. Sci. 9(3):285-300.

Duffus, D. A. and P. Dearden. 1990. Non-consumptive wildlife-oriented recreation: a conceptual framework. Biol. Conserv. 53:213-231.

Duffus, D. A. and P. Dearden. 1993. Recreational use, valuation, and management, of killer whales (Orcinus orca) on Canada's Pacific coast. Env. Conserv. 20(2):149-156.

Duffus, D.A. and K. J. Wipond. 1992. A review of the institutionalization of wildlife viewing in British Columbia, Canada. The Northwest Environmental Journal. 8:325-345.

Dufour, P. A. 1980. The effects of noise on wildlife and other animals: Review of research since 1971. EPA Rep. 550/9-80-100. 97 p.

Estes, J. A. and R. J. Jameson. 1988. A double-survey estimate for sighting probability of sea otters in California. J. Wildl. Manage. 52:70-76.

Estes, J. A., Underwood, K., and M. Karmann. 1986. Activity time budgets of sea otters in California. J. Wildl. Manage. 50:626-639.

Fowler, N. 1990. The 10 most common statistical errors. Bull. Ecol. Soc. Am. 71(3): 161-164.

Garshelis, D. L. and J. A. Garshelis. 1984. Movements and management of sea otters in Alaska. J. Wildl. Manage. 48(3):665-678. 
Gladwin, D. N. and K. M. Manci. 1988. Effects of aircraft noise and sonic booms on fish and wildlife: results of a survey of U.S. Fish and Wildlife Service endangered species and ecological services field offices, refuges, hatcheries, and research centers. US FWS NERC 88/30. 20pp.

Hurlbert, S. H. 1984. Pseudoreplication and the design of ecological field experiments. Ecol. Monographs 54(2): 187-211.

Kruse, S. 1991. The interactions between killer whales and boats in Johnstone Strait, B. C. pp.149-159 In: Pryor, K., and K. S. Norris (ed.), Dolphin societies: discoveries and puzzles. University of California Press, Berkeley. 397 p.

Majors, A. P. and A. C. Myrick Jr. 1990. Effects of noise on animals: implications for dolphins exposed to seal bombs in the eastern tropical Pacific purse-seine fishery: an annotated bibliography. NMFS Administrative Report Lj-90-06.

Manci, K. M., Gladwin, D. N., Villella, R., and M. G. Cavendish. 1988. Effects of aircraft noise and sonic booms on domestic animals and wildlife: a literature synthesis. US FWS NERC 88/29. 88pp.

Mansfield, A. W. 1983. The effects of vessel traffic in the Arctic on Marine Mammals and recommendations for future research. Canadian Technical Report of Fisheries and Aquatic Sciences No. 1186.

Mikola, J., Miettinen, M., Lehikoinen, E. and K. Lehtila. 1994. The effects of disturbance caused by boating on survival and behaviour of velvet scoter Melanitta fusca ducklings. Biol. Conserv. 67:119-124.

Miller, K. J. 1992. Approaching marine mammals. NOAA, NMFS, DEPT. COMMERCE. 50 CFR Parts 216,218. 
Norusis, M. J. 1994. SPSS advanced statistics. SPSS, Inc., Chicago. 606p.

Packard, J. M., and C. A. Ribic. 1982. Classification of the behavior of sea otters(Enhydra lutris). Can. J. Zool. 60:1362-1373.

Piatt, J. F., Roberts, B. D., Lidster, W. W., Wells, J. L., and S. A. Hatch. 1990. Effects of human disturbance on breeding least and crested auklets at St. Lawrence Island, Alaska. Auk 107:342-350.

Ralls, K., and D. B. Siniff. 1990. Time budgets and activity patterns in California sea otters. J. Wildl. Manage. 54(2):251-259.

Richardson, W. J., Davis, R. A., Evans, C. R., and P. Norton. 1985a. Distribution of bowheads and industrial activity, 980-84. p. 255-306 In: W. J. Richardson (ed.), Behavior, disturbance responses and distribution of bowhead whales Balaena mysticetus in the eastern Beaufort Sea, 1980-84. OCS Study MMS 85-0034. Rep. from LGL Ecol. Res. Assoc. Inc., Bryan, TX, for U.S. Minerals, Manage. Serv., Reston, VA. 306 p. NTIS PB87-124376.

Richardson, W. J., Wells, R. S., and B. Wursig. 1985b. Disturbance responses of bowheads, 1980-84. p. 89-196. In: W. J. Richardson (ed.), Behavior, disturbance responses and distribution of bowhead whales Balaena mysticetus in the eastern Beaufort Sea, 1980-84. OCS Study MMS 850034. Rep. from LGL Ecol. Res. Assoc. Inc., Bryan, TX, for U.S. Minerals, Manage. Serv., Reston, VA. 306 p. NTIS PB87-124376.

Richardson, W. J., Wursig, B., and C. R. Greene, Jr. 1986. Reaction of bowhead whales, Balaena mysticetus, to seismic exploration in the Canadian Beaufort Sea. J. Acoust. Soc. Am. 79(4):1117-1128.

Richardson, W. J., Greene Jr., C. R., Malme, C. I. and D. H. Thomson. 1991. Effects of noise on marine mammals. LGL Report TA834-1. 
Riedman, M. L. 1984a. Studies of the effects of experimentally produced noise associated with oil and gas exploration and development on sea otters in California. Final report to the Minerals Management Service, U.S. Dep. Inter., Alaska, 14-16-0009-78-937, 57pp.

Riedman, M. L. 1984b. Effects of sounds associated with petroleum industry activities on the behavior of sea otters in California. Pages D1-D12 in C.I. Malme, P.R. Miles, C.W. Clark, P. Tyack, and J.E. Bird. Investigations of the potential effects of underwater noise from petroleum industry activities on migratory gray whale behavior. Phase II. Final report to the Minerals Management Service, U.S. Dep. Inter. 14-12-0001-29033.

Riedman, M. L. and J. A. Estes. 1990. The sea otter (Enhydra lutris): behavior, ecology, and natural history. Biological Report 90(14).

Riedman, M. L., Estes, J. A., Staedler, M. M., Giles, A. A., and D. A. Carlson. 1994. Breeding patterns and reproductive success of California sea otters. J.Wildl. Manage. 58:391-399.

Shimek, S. J., and A. Monk. 1977. The daily activity of the sea otter off the Monterey Peninsula, California. J. Wildl. Manage. 41:277-283.

Smith, B. D. 1993. 1990 status and conservation of the Ganges river dolphin (Platanista gangetica) in the Karnali River, Nepal. Biol. Conserv. 66:159-169.

Sorensen, P. W., Medved, R. J., Hyman, M. A. M., and H. E. Winn. 1984. Distribution and abundance of cetaceans in the vicinity of human activities along the continental shelf of the northwestern Atlantic. Mar. Env. Res. 12:69-81.

Suryan, R. M. 1995. Pupping phenology, disturbance, movements, and dive patterns of the harbor seal (Phoca vitulina richardsi) off the northern San Juan Islands of Washington. M. S. Thesis, San Jose State Univ. $75 p$. 
Tabachnick, B. G. and L.S. Fidell. 1996. Using multivariate statistics. Harper Collins, New York. 880p.

Thiel, M., Nehls, G., Brager, S., and J. Meissner. 1992. The impact of boating on the distribution of seals and moulting ducks in the Wadden Sea of Schleswig-Holstein. Netherlands Institute for Sea Research.

Publication series \#20. pp.221-233.

VanDerZande, A. N. and T. J. Verstrael. 1985. Impacts of outdoor recreation upon nest-site choice and breeding success of the kestrel. Ardea (73):90-99.

Watkins, W. A. 1986. Whale reactions to human activities in Cape Cod waters. Marine Mammal Science. 2(4):251-262.

\section{Personal Communications}

James A. Estes, National Biological Survey, Institute of Marine Sciences, University of California, Santa Cruz.

Brian B. Hatfield, National Biological Survey, San Simeon, California.

Jerry Loomis, Point Lobos State Reserve, Carmel, California.

Marianne L. Riedman, Institute of Marine Sciences, University of California, Santa Cruz.

Thomas D. Williams, Monterey Bay Aquarium, Monterey, California. 
Table 1. Classification of sea otter discrete action patterns used in this study into functional behavioral states (based on Packard and Ribic 1982).

FUNCTIONAL BEHAVIORAL STATE

DISCRETE ACTION PATTERNS

RESTING

-Floating

-Rocking

-Logrolling

-Somersaulting

-Looking

GROOMING

-Nibble/Lick

-Rubbing

-Shaking

-Stroke

FORAGING

-Eating

-Periscoping

-Submerged

-Pounding

-Eating while Sculling

LOCOMOTION

-Dive

-Porpoising

-Sculling

-Surface Swimming

-Sidestroke

-Underwater swimming

INTERACTION

-Chasing

-Wrestling

-Biting

-Lunging

-Giving

-Other 
Table 2. Types and levels of disturbance (kayaks, boats, and divers) for the four areas with disturbance in Monterey Bay, California. The number of observation periods $(n)$ is given for each area.

\begin{tabular}{|c|c|c|c|c|c|c|}
\hline Location & & Kayaks & Boats & Divers & $\begin{array}{c}\text { Total } \\
\text { Disturbances }\end{array}$ & Sample \\
\hline \multirow[t]{2}{*}{$\mathrm{HD}-1$} & Totals & 182 & 37 & 19 & 238 & $n=21$ \\
\hline & Percent & $76.5 \%$ & $15.5 \%$ & $8.0 \%$ & & \\
\hline \multirow[t]{2}{*}{$\mathrm{HD}-2$} & Totals & 309 & 52 & 35 & 396 & $n=49$ \\
\hline & Percent & $78.0 \%$ & $13.1 \%$ & $8.8 \%$ & & \\
\hline \multirow[t]{2}{*}{ HD-3 } & Totals & 2 & 6 & 43 & 51 & $n=23$ \\
\hline & Percent & $3.9 \%$ & $11.8 \%$ & $84.3 \%$ & & \\
\hline \multirow[t]{2}{*}{$\mathrm{HD}-4$} & Totals & 3 & 10 & 17 & 30 & $n=19$ \\
\hline & Percent & $10.0 \%$ & $33.3 \%$ & $56.7 \%$ & & \\
\hline \multicolumn{7}{|c|}{ HD-1 = near-shore waters around Cannery Row } \\
\hline \multicolumn{7}{|c|}{$\begin{array}{l}\text { HD-2 }=\text { near-shore waters adjacent to Monterey coast guard wharf } \\
\text { HD-3 = Whalers Cove }\end{array}$} \\
\hline
\end{tabular}




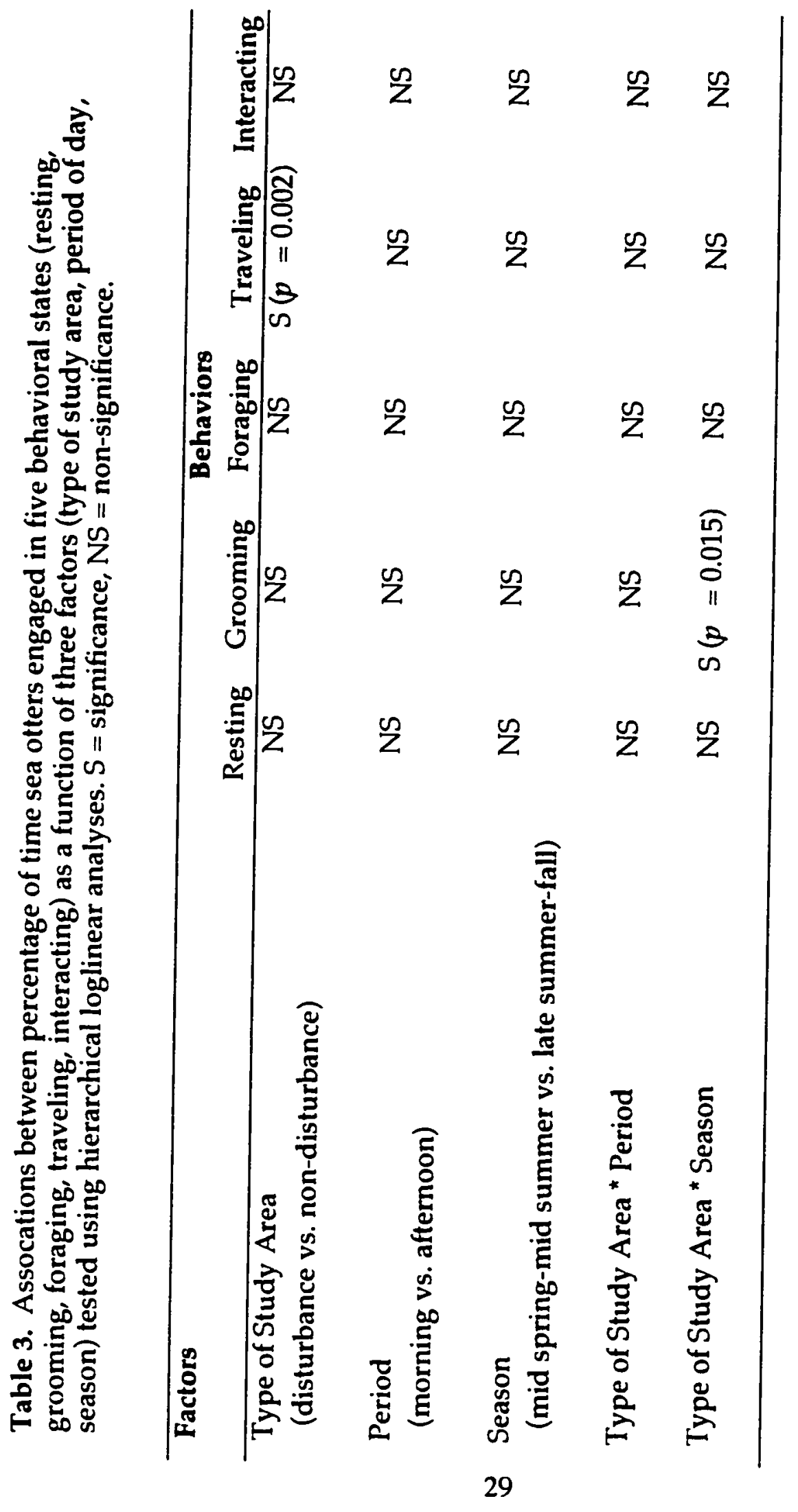




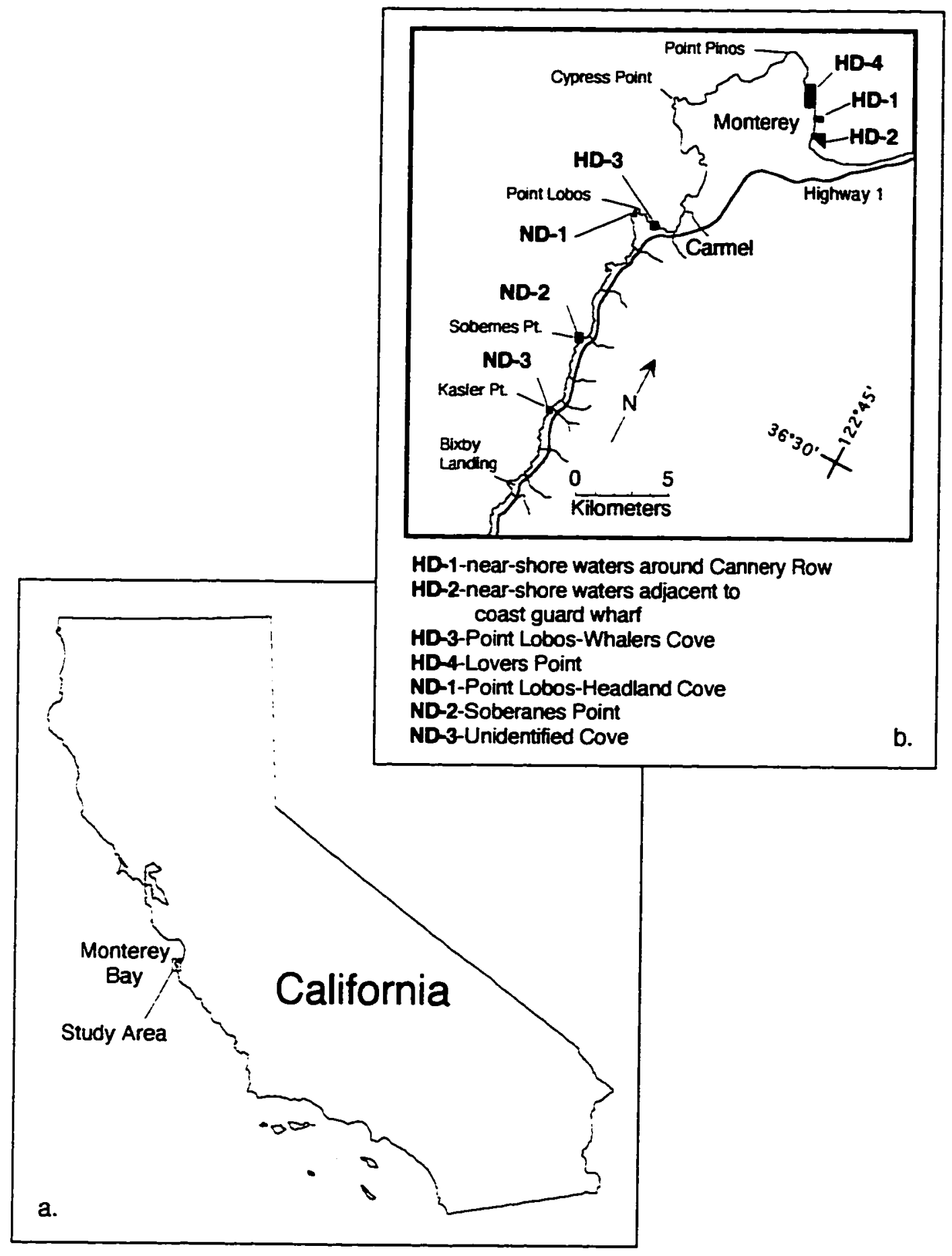

Figure $1 \mathbf{a}, \mathbf{b}$. Location of Monterey Bay, California study areas (a) for specified sites with and without disturbance along the Monterey peninsula (b). $\mathrm{HD}=$ high disturbance, $\mathrm{ND}=$ no disturbance. 


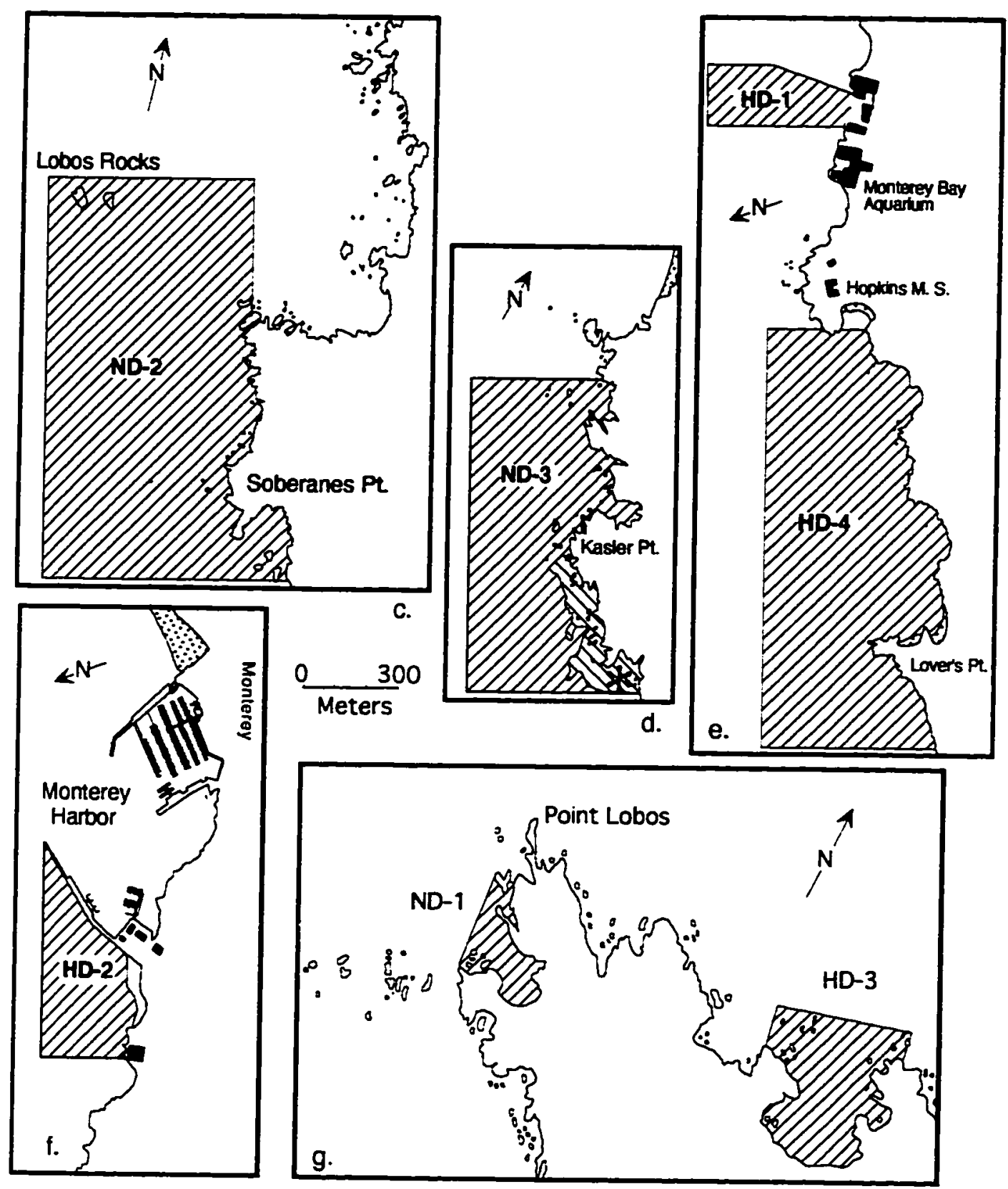

Figure $1 \mathrm{c}-\mathrm{g}$. Locations and boundaries (indicated by hatching) of individual study areas with (HD) and without (ND) disturbance in Monterey Bay, California. 


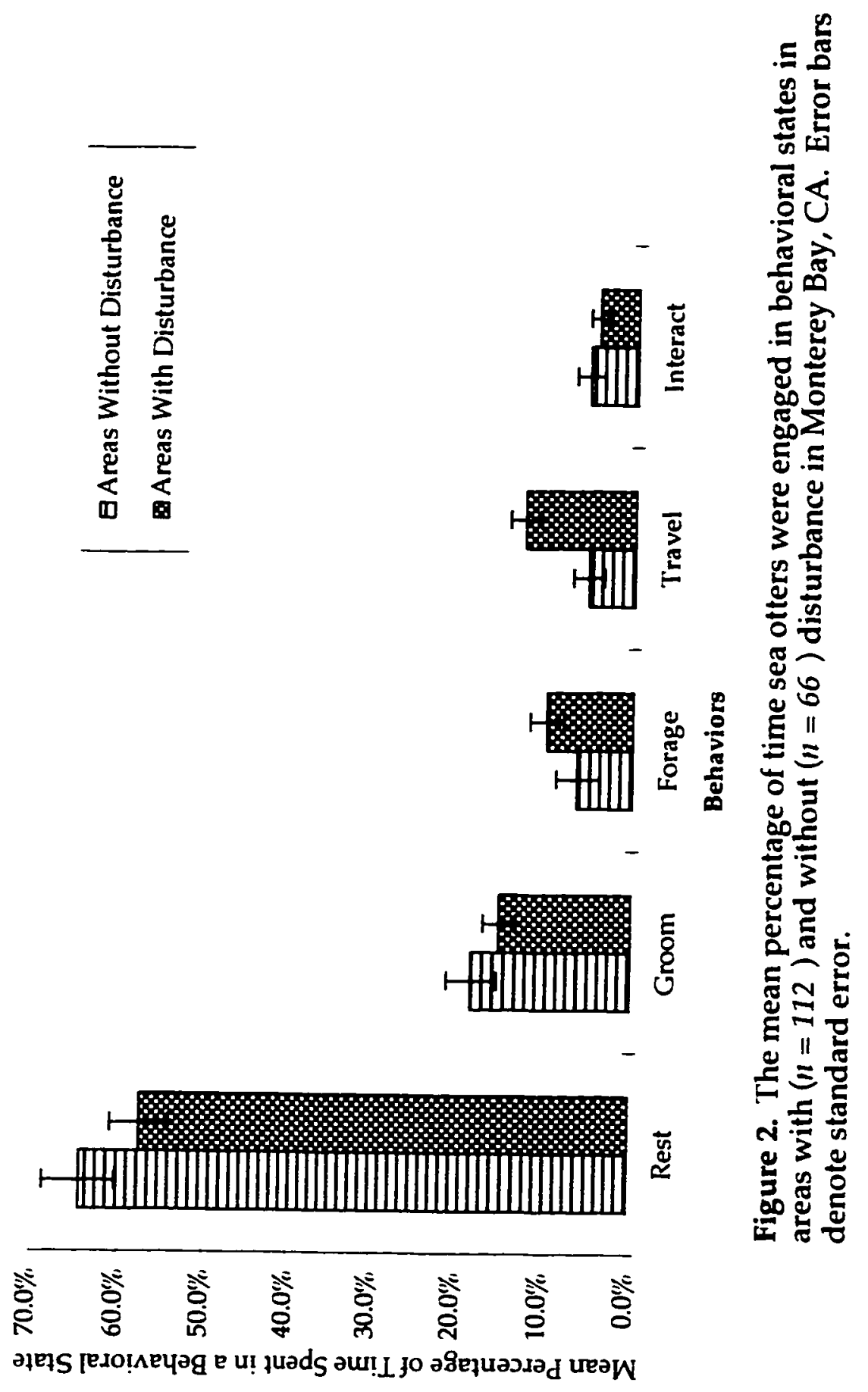




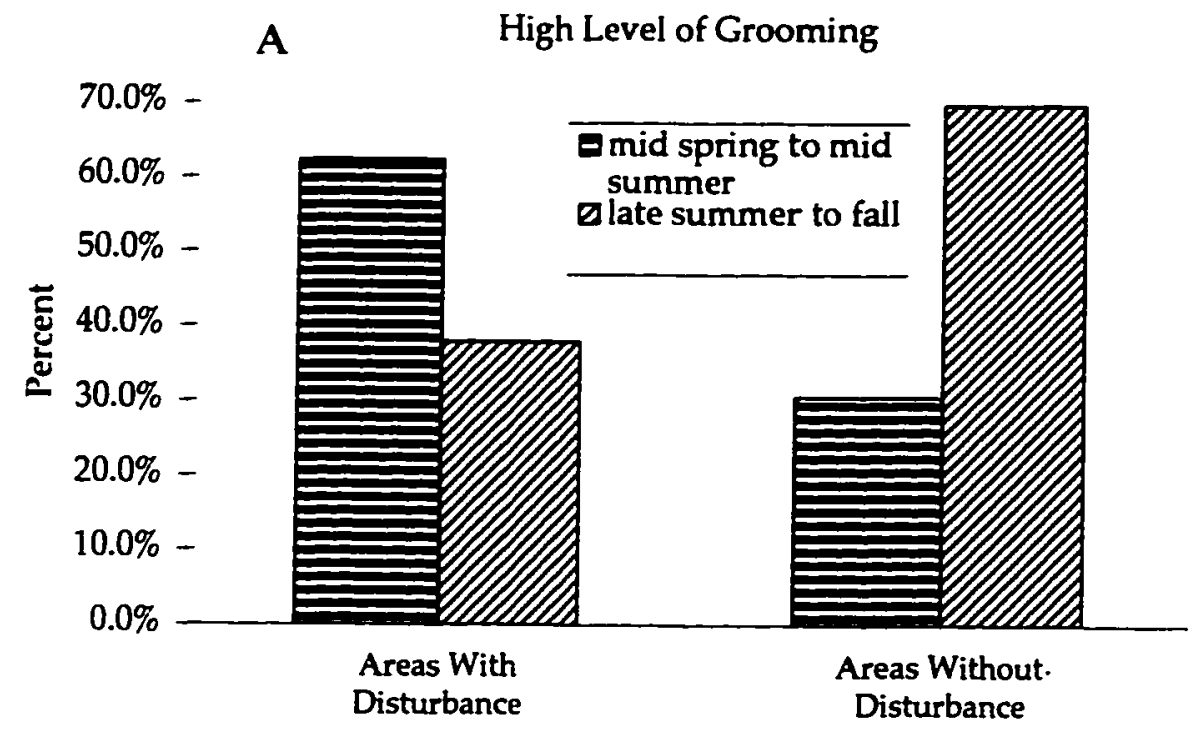

Study Areas

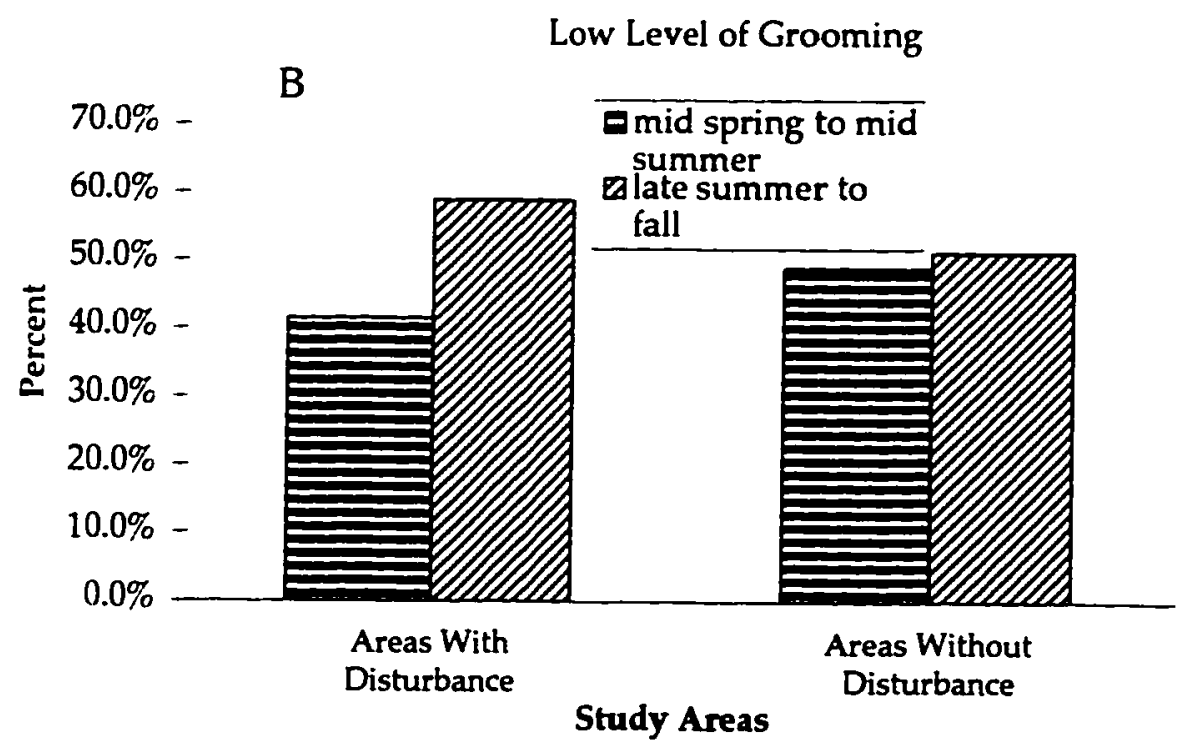

Figure 3. The percentage of time sea otters spent in high (A) and low levels (B) of grooming in areas with disturbance $(n=112)$ and without disturbance $(n=66)$. The total percentage of time for each level of grooming (high, low) in areas with and without disturbance was compared between seasons (mid spring to mid summer, late summer to fall). 


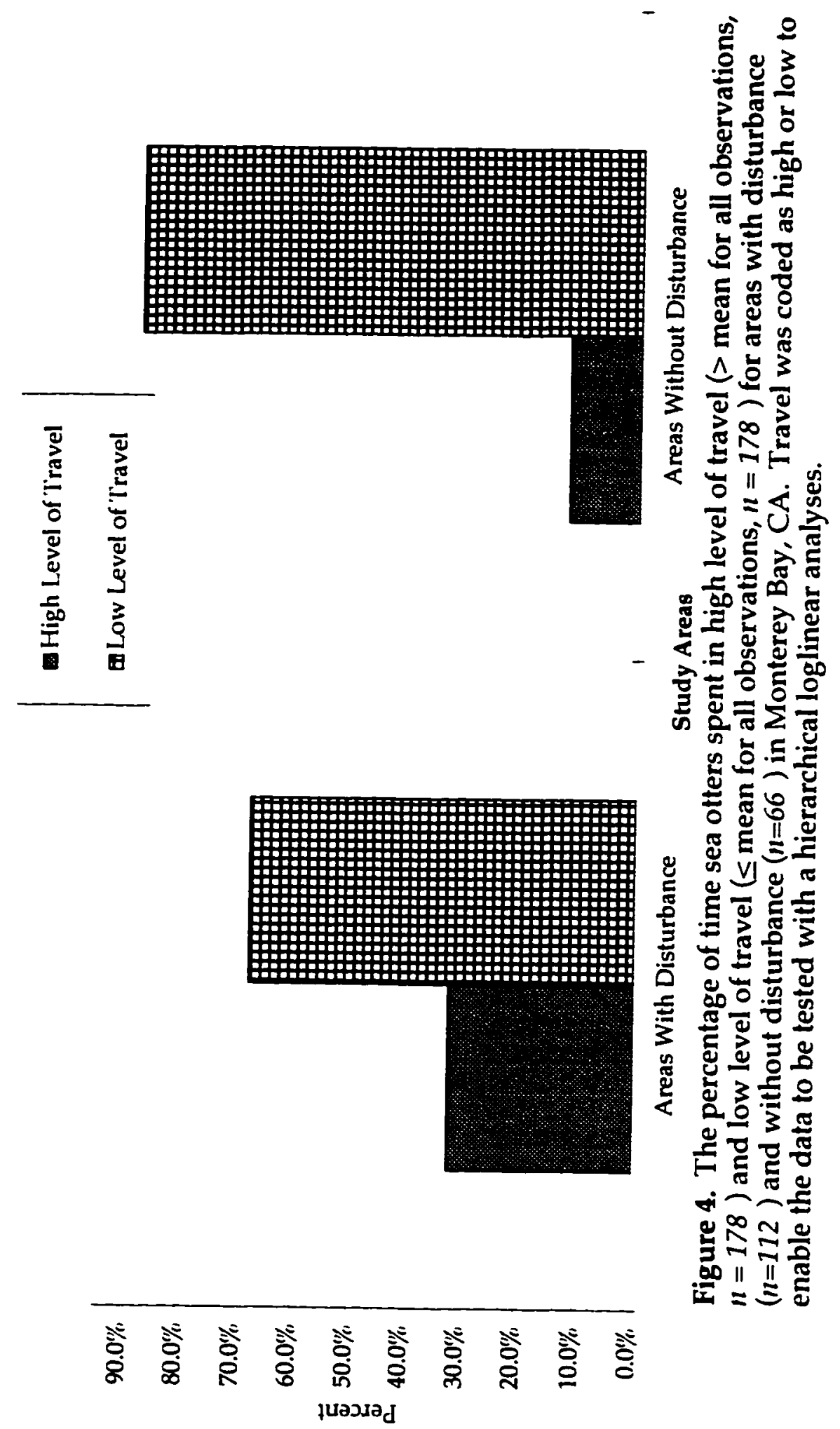

